\title{
Chapter 2 \\ Historic Milestones of Human River Uses and Ecological Impacts
}

\author{
Gertrud Haidvogl
}

\subsection{Introduction}

History has been acknowledged for 20 years as an important research element for river management that has been applied, for example, to define reference conditions and assess the level of degradation. The evolution of river uses and related ecological conditions, especially in recent decades, has been utilized to show the impact of humans on these ecosystems. Integrating a historical perspective into river management can, however, go beyond these targets (see, e.g., Haidvogl et al. 2014, 2015; Higgs et al. 2014). Just as present river management decisions will influence future conditions, paths trodden by users in the past have a bearing on today's ecology. Sound long-term studies of the natural and societal drivers shaping historical river changes can thus support our understanding of the present situation and identify trajectories of change. In long-term studies taking into account the dynamics of natural forces - in particular climate change and subsequent altered hydrologic and temperature conditions - as well as social dynamics (e.g., decision-making processes, main energy sources and technologies, superordinated practices and values) can reveal distinct overarching patterns of river use and management. This can contribute to developing future strategies and plans with lower ecological impacts.

This chapter describes major milestones of human river uses and ecological impacts. With some brief mention of Asian river case studies, it highlights especially examples, which are representative of industrialized countries of Europe and North America. In Europe, larger environmental changes of aquatic ecosystems occurred already in ancient and medieval times. European colonists spread practices and techniques of river uses to other areas of the industrialized world after they reached

\footnotetext{
G. Haidvogl $(\bowtie)$

Institute of Hydrobiology and Aquatic Ecosystem Management, University of Natural

Resources and Life Sciences, Vienna, Austria

e-mail: gertrud.haidvogl@boku.ac.at
} 
regions, which have previously only been influenced by indigenous people (e.g., Humphries and Winemiller 2009). In the global North, the main milestone of historical river uses and subsequent ecological impacts was certainly the shift from agrarian to industrialized societies in the eighteenth and nineteenth centuries. Accordingly, preindustrial and industrialized rivers exhibit large differences in their ecological functioning as well as in the intensity of human impacts. Shifting from the preindustrial to the industrial mode of living resulted from the change of the prime energy source. While the former depended on wood, the latter requires exploitation of fossil energy, first coal, and, shortly before and particularly after World War II, oil (Sieferle 2006). Fossil fuels offered among others new transport means and possibilities for trading as well as unprecedented options to modify riverine environments. Fossil fuels enabled the systematic channelization of rivers and supported their damming or stocking of nonnative species on a global scale. Industrialization loosened the century-long tight connection of major parts of societies from their local and regional environmental resources and gave way to new practices of exploiting riverine ecosystem services.

\subsection{Historical River Uses and Resulting Impacts}

\subsubsection{General Patterns of River Uses}

Rivers provide ecosystem services that have attracted humans for millennia (see Chap. 21). Archaeological and later written evidence provide proof that river uses and necessary technical infrastructures existed already in ancient times, especially in arid zones. The Sadd-el-Kafara Dam on the Nile built some $30 \mathrm{~km}$ south of Cairo about 4500 years ago is considered as one of the oldest constructions of its kind (Hassan 2011). Major rivers such as the Nile, the Euphrates, the Indus, and the Jangtsekiang enabled cultures to develop and shaped their economy and culture.

In Europe, the Greek and Roman civilizations started influencing rivers, especially in urban areas to which water was delivered by aqueducts. With the collapse of the Roman Empire, technologically supported water uses diminished quickly in areas colonized by Romans. For several hundred years, they were replaced by rather local and small-scale river uses except for Spain, where the Muslims introduced water wheels and mills after the seventh century (Downs and Gregory 2004; Hassan 2011).

Outside of Europe, continuing technological progress and practices of river use as well as possible ecological effects linked to demographic and economic development can be deduced from the dams built, e.g., in Japan during the European "Dark Ages." The World Commission on Large Dams lists 20 dams higher than $15 \mathrm{~m}$, which were built between 130 and 1492 CE. Most of these (i.e., 14) existed in Japan, and one each in India and Afghanistan. In Europe, by the Early to Late Middle Ages only one dam erected in $130 \mathrm{CE}$ in Spain remained. Larger dam construction started only during the Late Middle Ages: In the present Czech Republic between the 
thirteenth and fifteenth centuries, three facilities were erected to create fishponds (ICOLD—International Commission on Large Dams 2016).

In most European countries and in North America, rivers served a large variety of human uses up until the beginning of the industrial era in the late eighteenth and nineteenth centuries. In preindustrial times most parts of society depended on local and regional environmental resources, often brought to them by rivers. This constituted their strategic importance. Different societal demands on rivers had to be harmonized to minimize adverse impacts on riverine services. Rivers and brooks were the main source of kinetic energy. They were the main transport routes, either for shipping goods or for transporting wood via rafts, sometimes with goods on it. In the case of very small brooks, wood was driven as loose logs, often during seasonal flooding. Although drinking water came often from groundwater wells, surface waters were sources, too. Surface water was a direct resource for many activities. It was used for cleansing and served many commercial purposes that had an adverse effect on water quality for drinking and cleaning. In urban areas and settlements, any local stream received the waste and wastewater from dwellers. It has to be noted, however, that the latter was rather limited as long as a majority of people depended on wells and their limited water quantities. Wastewater volumes significantly increased starting in the late nineteenth and twentieth centuries, as rapidly increasing urban populations required larger-scale and more sophisticated water management. As a result, central water pipelines supplying individual buildings and their households were built. Aquatic biodiversity is an essential component of ecosystem services, and riverine animals and plants played an important role for local food provision. Fish were central to the diets of many regions, especially for settlers along coastal rivers, but also in Christian countries in continental areas. Frogs, mussels, and even beavers were also used as food and, in the latter case, for fur. Floodplain forests helped to meet the heavy demands for wood as a basic energy source for preindustrial societies.

Growing demand from increasing human populations and the expanding economies of growing settlements and towns intensified all these preindustrial river uses. At the onset of industrialization around the beginning of the nineteenth century, human river uses have been maximized as far as possible in large areas of the Western world. But the exploitation of the various riverine ecosystem services was still limited to the local and regional scales, and finding compromises to mitigate adverse effects of one type of use on the other remained a prerequisite.

"Industrialized rivers" differ fundamentally from preindustrial ones. The shift from wood to fossil fuels enabled river engineers to carry out large-scale systematic regulation projects for navigation or flood protection especially on dynamic large rivers. New technologies produced and conducted electricity from hydropower plants to cities and factories, making electricity production spatially independent from the place of use. Travel times decreased and trade volumes increased with the rise of ships and railways driven by fossil fuels (first coal, then petroleum). Preindustrial patterns of river use and resulting ecological impacts ceased to exist. No longer did local and regional rivers serve all purposes that depended on water. For example, drinking and process water could be brought into cities from distant 

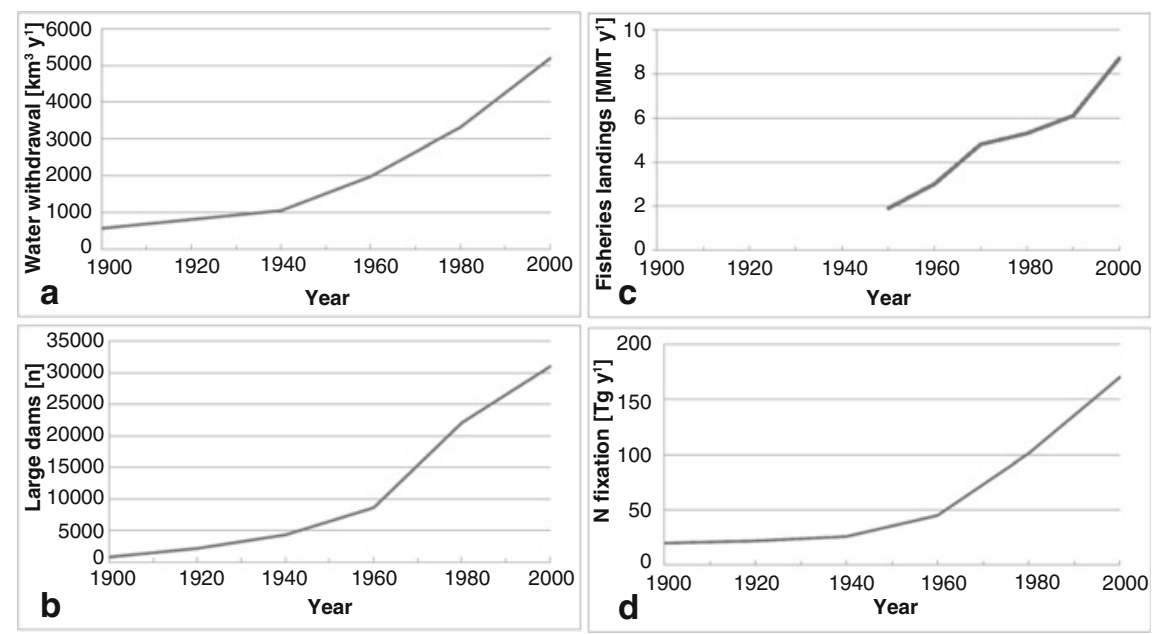

Fig. 2.1 The evolution of human pressure on rivers and freshwater systems in the twentieth century; the examples demonstrate the often exponential increase after World War II. (a) Global water withdrawals 1900-2000 (estimation for 2000); (b) Number of large dams (higher than $15 \mathrm{~m}$ ) 1900-2000; (c) Fisheries landings from inland waters 1950-2000; (d) Global inputs of anthropogenically fixed nitrogen; adapted from Gleick 1993 (a), ICOLD 2007 (b), Allan et al. 2005 (c), Vitousek 1994 (d) and Strayer and Dudgeon 2010

rivers and springs, increasing the environmental imprint of urban centers in spatial terms (see, e.g., Billen et al. 2012). Large quantities of fish could be imported from the sea to continental consumers in reasonable times, thus eliminating the need to protect local stocks. Also, food supply based on improving transport started to affect watersheds on a global scale far away from the places of consumption (Vörösmarty et al. 2015).

The industrialization of rivers happened gradually and with increasing pace (see Fig. 2.1). Along with human uses, the resultant ecological impacts increased exponentially, especially after the 1950s. Until the late nineteenth century, often features from the preceding preindustrial period prevailed. For instance, defying elimination by fossil fuels, water mills had grown and become more complex so as to drive sophisticated machinery, to cool water, to improve power generation, to irrigate agricultural land, and/or to secure water supply (Downs and Gregory 2004). But generally, in the nineteenth century and thereafter, shifts in technology, cultural practices, administration, and policy reflected their new roles in river management, especially in European and North American countries. Management of river risks entered a new era. Active flood protection based on dikes became more and more common. It replaced preindustrial strategies of passive flood protection, which aimed at measures to keep damages to goods and lives as low as possible but not at preventing flooding at all (see Chap. 28). Technological and administrative innovations shifted the perspective of the industrial societies toward river ecosystems. The increasing capacity to substitute for river ecosystem services, regardless of 
distance, eliminated the need to harmonize a large variety of different uses (Jakobsson 2002). This resulted in maximizing one or two river uses, often those that did not adversely affect each other, e.g., power and transport. Other river uses, often fish and fisheries, were given up in favor of the preferred river services. After the 1970s, the negative effects of human impacts on ecological conditions received more and more attention, and river restoration projects have been started. This went hand in hand with thorough scientific observations of the links between human river alterations and biodiversity as well as animal and plant stocks often enabling for the first time to trace ecological changes based on direct field observations.

The following examples of human river uses and ecological impacts can be taken as fairly general, especially for the industrialized world, although with few exceptions (see Zarfl et al. 2015) no global or even continental overviews on the historical development of river uses and ecological impacts exist.

\subsubsection{Milestones of Dam Building}

Dams are one example of the increasing pressure on river services. Mostly, dams were built to gain hydropower, but they supported also the creation of fishponds or, in dryer areas, irrigation of agricultural land. The number of weirs increased throughout the High and Late Middle Ages and thereafter. For instance, in England, where the oldest comprehensive report exists in the form of the Domesday Book from 1086, 5642 mill weirs were recorded for this time. For France it is assumed that in the beginning of the twelfth century 20,000 dams were operated. Two centuries after, the number had risen to 40,000 , and by the end of the fifteenth century (i.e., the end of the Middle Ages), 70,000 dams had been constructed (Braudel 1986). Certainly, the increase in numbers followed the expansion of populations, especially in cities with the increasing wealth of urban dwellers. Bork et al. (1998) added an environmental argument (so-called Wassermühlenthese, i.e., "water mill thesis") to the rising number of mills. According to their historical and paleographic study of German landscapes north of the Alps, in the fourteenth century, land-use change, especially forest clearing for the benefit of arable land, meadows, and pastures, reduced transpiration and caused rising groundwater levels. This made springs more abundant and their increasing runoffs were a suitable basis to construct mill weirs. From the turn of the eighteenth to the nineteenth century, it is estimated that in Europe the number of weirs amounted to 500,000-600,000 (Braudel 1986). One can assume, however, that this estimate relates only to larger weirs, while the total number was much higher. For example, a case study of an Austrian alpine river catchment (Möll River in Carinthia) showed that in the 25 communities located along this approx. 80-km-long river and its tributaries, 750 hydropower facilities existed (Haidvogl and Preis 2003, unpublished dataset).

It is evident that already preindustrial weirs-though small compared to modern dams - had modified ecological conditions. They acted as sediment traps and altered channel morphology not least due to their tremendous number. In small, 
anabranching streams in the mid-Atlantic region of North America, no significant amounts of sediment accumulated before European colonization in the seventeenth century. After European settlers had built thousands of milldams between the seventeenth and nineteenth centuries, 1-5 m of slack water sedimentation had covered the floodplains and the present meandering river channels incised in these sediments (Walter and Merritts 2008).

The impacts of weirs, especially on fish migration, have been known and addressed for centuries (see Chaps. 6 and 9). In preindustrial times, when harmonizing various river uses on local scales was a necessity, finding compromise was key. Although neither historical observations nor fishery records have been kept, this is evident from water legislation. A Scottish statute of 1214 demanded, for instance, openings in dams, and all barrier nets had to be lifted on Saturdays to allow salmon runs (Salmo salar, Hoffmann 1996). A fishing decree from 1545 for the Austrian Traisen River, a right-hand tributary of the Danube, provides similar protections for potamodromous fish species (Raab 1978). For tributaries of Alpenrhein (Rhine upstream of Lake Constance), fish passes were planned already in the sixteenth century. Along the Ill River, such a technical facility should have re-enabled migration of lake trout, which was interrupted by a dam to withdraw drinking and process water for the commune Feldkirch. This dam replaced an older and lower construction that was destroyed by a flood in 1566 . Some decades later, the manorial lords upstream raised an official complaint because their main fishing target was missed. A fish bypass was suggested as possible solution but never built due to the technical problems of such a construction in the schistose rocks (Zösmair 1886). A fish pass was however realized on the Albula River, a tributary of Hinterrhein in the Swiss canton Graubünden, after millers erected a new dam in the 1680s and interrupted lake trout migration. The passage had a length of $6 \mathrm{~m}$ and a width of $1.5 \mathrm{~m}$ (Bundi 1988).

In the late nineteenth and especially in the twentieth century, the number of dams rose exponentially around the globe, first in the North and then in the South (see Chaps. 1 and 6). They continued to serve century-long functions especially as hydropower producers and for irrigation. New technologies and machinery built with ever-cheaper steel and powered by fossil energy helped to create concrete edifices of $100 \mathrm{~m}$ height and more. Together with the necessary means to transform mechanic energy into electricity and to transmit this electricity over large distances, large manufacturers and railways and urban administration soon started to benefit. After World War II, electricity use rose, not least with domestic demand for household appliances. In arid regions, dams and reservoirs secured irrigation of agricultural land. A summary on dam construction in the twentieth century demonstrates the increasing pace of large dam building after 1950 (Rosenberg et al. 2000). By 1900, several hundreds of large dams (i.e., equal or higher than $15 \mathrm{~m}$; International Commission on Large Dams) existed. Up until 1950, the total global number newly built per decade was less than 1000 . During the 1950s, almost 3000 new dam projects were implemented. In the 1970s, the number peaked at more than new 5400 facilities. In the 1990s, still almost 2000 new constructions occurred globally. In the 2000s and 2010s, the number further decreased, but, e.g., Zarfl et al. (2015) assume 


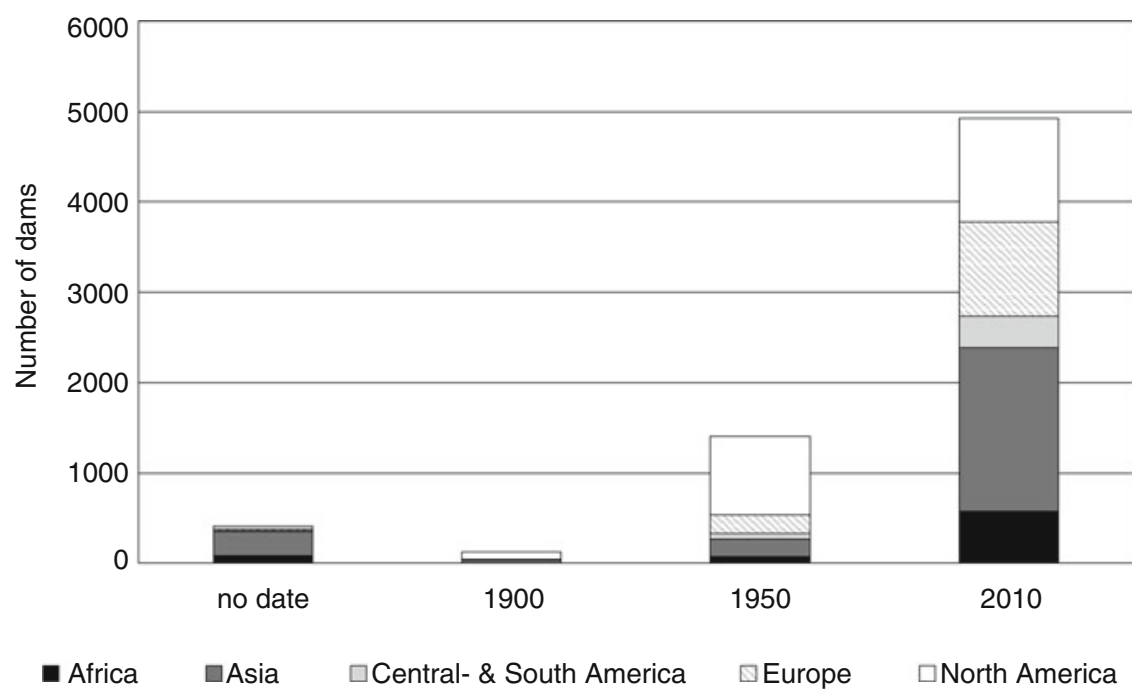

Fig. 2.2 Increase of number of large dams in different geographical areas 1900, 1950, 2009 (Europe includes Russia; based on GRanD-database, Global Water System Project (C) 2010, Lehner et al. 2011a, b)

that in the 2020s thereafter new dam construction will resume (see also Lehner et al. 2011a) (Fig. 2.2).

The ecological effects of modern dams are manifold (see, e.g., Poff and Hart 2002; see Chap. 6). They reduce velocity and often create almost stagnant waters of varying size; they change water temperature, which influences bioenergetics and vital rates of organisms. Downstream movement of water and sediment is influenced and reduced with adverse effect on river and riparian habitats, and biogeochemical cycles are modified. Dams hamper migration of fish and other aquatic organisms and exchange of nutrients up- and downstream. Almost half of present larger dams are used for irrigation (International Commission on Large Dams; http://www.icoldcigb.org/, Accessed 18 Jul 2016). Water abstraction via dams and reservoirs caused some of the most striking examples of environmental degradation in the last decades. For example, after a severe drought in 1946, the former USSR initiated large-scale dam constructions to redistribute available water resources. The Aral Sea is a prominent case for environmental degradation as it suffers from reduced water inflow due to water abstraction in the main tributaries since the 1960s (Micklin 2007). 


\subsubsection{River Channelization to Secure Transport and Land Use}

There is no direct link between historical river transport and land use in floodplains. However, these two human river system uses have to be perceived as connected, as both required channelization measures. Accordingly, activities evolved centuries ago to prevent erosion of cultivated land and, in particular, to secure navigation. Initial measures focused on stabilizing riverbeds and riverbanks, while flood protection dikes to avoid inundation of settlements became more typical only in and after the nineteenth century with industrialization and subsequent population growth and spread of settlements into floodplains.

Transport has been an essential function of rivers for millennia. It characterizes virtually all rivers that attracted settlement. Just as with hydropower use, its intensity grew with rising population and trading of agrarian, preindustrial societies. Generally, river transport was cheaper and, often, even safer than that on roads, though it was at the same time slower. In addition, navigation, rafting, or log driving was affected by yearly natural cycles, especially low- and high-flow periods or freezing, as typical for alpine and continental regions (e.g., Pounds 1979). Hence, it was the main option for trading bulky goods and, in particular, wood (Pounds 1979; Möser 2008, Sieferle 2008). To support smooth navigation, riverbanks were often fixed and obstacles such as boulders removed manually from rivers or blasted, for instance, on the Austrian Danube in the late eighteenth century (Petts et al. 1989; Hohensinner et al. 2013).

To complement the transport network offered by natural waterways, artificial canals were introduced. In Europe, the first attempts to construct artificial shipping canals date back to Roman Times, e.g., in the Netherlands (Corbulo, Drusus canals) and France (Vella et al. 1999), or to the Early Middle Ages, when Charlemagne projected the Fossa Carolina in 793 (see, e.g., Brolsma 2011; Leitholdt et al. 2012). Charlemagne's plan was far beyond the technologies available at that time, and the canal remained a 3-km-long fragment. In Asia, the approx. 1770-km-long BeijingHangzhou Grand Canal was built as strategic waterway before the end of the thirteenth century. It linked five river basins and transferred water from Yangtze to North China Plain (Gregory 2006). By 1411, the Grand Canal was further developed and fed, among others, by water of the Lower Yellow River's main channel, which was stabilized to provide continuous flow (Overeem et al. 2013). To avoid a northward breach of the Yellow River and subsequent damage to the canal, a continuous levee was built on the north bank of the Yellow River and completed in 1494. On the southward banks, breaches diverted water toward the distributaries of the Huai River as flood control measures.

In Europe, in the seventeenth century, first projects in the Netherlands or in France (Canal du Midi) initiated a canal building boom that continued for the next two centuries (Brolsma 2011). Projects became much more ambitious, e.g., as proposals for connections between major European rivers such as Danube, Elbe, or Oder show (see, e.g., Vogemont 1712). Inland canal building continued well into 
the twentieth century. For example, as the connection between the Black and the North Sea was envisioned by Charlemagne already in the eighth century, the RhineMain-Danube Canal became reality only in the 1990s. It can be assumed that, since their completion, artificial canals have supported the dispersal of aquatic animals, in particular fish, to new river systems. The nase (Chondrostoma nasus), for instance, entered French rivers via shipping canals at the latest in the second half of the nineteenth century. The expansion of this species is confirmed for the 1860 s for the Rhine and a new canal system in north-eastern France. Its occurrence was soon after observed in the Seine, then in the Upper Loire and Rhone basins where it arrived within less than 40 years (Nelva 1997).

In the 1830s, steam-driven railways started to operate, and railway connections intensified quickly in Europe as well as in North America (see, e.g., Pounds 1979 for Europe). Navigation was forced to react to the growing competition, usually by increasing ecological pressures on rivers. Since the first decades of the nineteenth century, the sophistication of steam technology also powered ships, freeing them from the need for tow roads and teams on the riverbanks. Compared to the wooden ships, their requirements for space in the river channel were much stricter, e.g., regarding homogenous and larger river cross sections. Steam ships soon increased in size, boosting the pressure for straightening and channelizing rivers with wellknown ecological consequences (see Chap. 3).

While river channelization for navigation dates back centuries, flood protection is more typical for industrialized rivers. In the late nineteenth and twentieth century, previously not intensively used floodplains were newly colonized as urban areas. In the Middle Ages and Early Modern Period, neither settlements nor agricultural lands were protected from floods. It was rather common to adapt land use as much as possible to flooding, e.g., by preferences for elevated terrain and lower water depths during floods. This has been proven for arable land in the Austrian Danube floodplains in the Machland or for settlements in Vienna (see, e.g., Haidvogl 2008; Haidvogl et al. 2013). Large-scale flood protection measures-often implemented in conjunction with hydropower dams and waterway improvement for shipping - resulted in hydraulic disconnection of areas that previously had been flooded regularly. Cutoff from normal river channel flows as well as, even more importantly, flood pulses, floodplain waters stagnated and filled with sediments and organic matter, raising floodplain elevation and finally drying up (see, e.g., Hohensinner et al. 2004).

\subsubsection{Water Supply from Rivers: Increasing Imprint on Urban Hinterland}

Rivers were essential water resources in particular for various commercial purposes. In urban areas, they became centers of economy. Washers, tanners, dyers, beer brewers, or slaughterhouses, for example, used them likewise for cleaning and 
washing. Often this resulted in serious conflicts in water demand between water polluters and other commercial ventures requiring clean water (see, e.g., Billen et al. 1999). Drinking water was often withdrawn from local groundwater sources, although surface waters were used as well, as the example of urban centers such as St. Petersburg shows (Kraikovsky and Lajus 2010). In the nineteenth century, population growth and urbanization increased the pressure on drinking and process water supply. As characteristic for the industrial period, the growing metropoles were driven by the declining quantity and/or quality of water supply to cross the boundaries of their local and regional river catchments. Via water pipelines, they tapped sources far away and transferred also their ecological imprint to other more suitable regions. Prime European examples include Paris (Barles 2012) and Vienna (Gierlinger et al. 2013). Enlarged water supplies often resulted in an enormous growth of water use per capita, sometimes continuing until present times. The Greek capital Athens, for instance, started to search for new water resources outside of the immediate urban surroundings in the 1830s. Since then, water supply infrastructures to tap distant sources have been expanded gradually. At present, Athens controls a significant amount of water reserves of two Greek river basins and no attempts have been made to decrease per capita demand of urban population (Stergiouli and Hadjibiros 2012). A similar historical trend can be observed for Barcelona, with the exception of successful recent efforts to reduce urban water consumption (Tello and Ostos 2012). In mid-nineteenth century, Boston pipelines brought water 20 miles from Lake Cochituate after the local wells became so polluted that they could no longer be used without danger to the lives of urban dwellers. In the 1860s, the city incorporated several communities to extend and secure its water resources. Bostonians used in the 1860s 100 gallons per person per day (approx. 380 L) in contrast to 3-5 gallons (approx. 11-19 L) when water came from wells (Vörösmarty et al. 2015). New York abstracted water from a tributary of the Hudson after erecting the New Croton Dam that was the world's largest masonry dam at its completion in 1906 (Vörösmarty et al. 2015).

As a general historical tendency, more drinking and process water increased the volume of wastewater released into rivers. Newly built centralized sewage systems initiated point-source pollution, built in urban areas since the late nineteenth century, to fight against hygienic nuisance and infectious diseases, such as cholera.

\subsubsection{Pollution of Rivers and Its Legacies}

Waste-for long historical periods mostly of organic origin —increased the nutrient load in aquatic ecosystems. Centuries ago, smaller and mid-sized rivers suffered certainly more than large ones because of their lower dilution capacity. Medieval castles and monasteries had often a direct connection between their latrines and local rivers (Hoffmann 1996). Already in the beginning of the fourteenth century, Paris effluents had turned the Seine into an infectious and foul canal (Mieck 1981). The quantities of waste were however considerably smaller before the 1900s. For 
example, human and animal excreta were considered as valuable nutrient resources since agrarian societies depended solely on natural fertilizers for grain production. Only in the late nineteenth century did it become a general habit to flush and dispose, respectively, human and animal excreta. By then, Justus von Liebig's discoveries of the role of nutrients for plants, his invention of a phosphorous fertilizer in 1843, as well as the import of guano and "Chile saltpetre" by steam ship navigation improved the fertilizer sources for European agriculture. Sewage farms collecting in particular organic waste from towns had their heyday in the first decades of the twentieth century. However, the invention of the Haber-Bosch process in 1910 relieved farmers for the first time in history fully from their dependence on natural fertilizers. This had far-reaching consequences for rivers. For example, for the Seine, it was demonstrated that in 1817 when 716,000 dwellers and 16,500 horses lived within the urban borders the amount of nitrogen released into the Seine was negligible. The larger part was returned to the agricultural lands that provided the city in turn with food and feed. A hundred years later, in 1913 when 2,893,000 inhabitants and 55,000 horses lived in Paris, 3100 tons of nitrogen were released annually into the river via central sewers, which were built in the meantime. Still, however, the larger proportion of nitrogen was collected for agriculture, mostly in the large sewage farms along the Seine banks downstream of Paris (i.e., 9100 tons/year; Barles 2007).

On a global scale, Green et al. (2004) compared the change of riverine nitrogen fluxes of the preindustrial era and nowadays. The largest preindustrial flux was found for the Amazon exceeding a load of 3.3 million MT N/year at the river mouth. At present, the largest amounts are closely linked to industrialized areas, e.g., continental Europe, North America, as well as Southern and Southeast Asia. As for nitrogen, eutrophication as a result of excessive phosphorus input became an increasing problem for rivers in the second half of the twentieth century (see, e.g., Liu et al. 2012).

While organic river pollution can produce effects over the short- and midterm, other types of historical pollution will remain for decades and even centuries. The current release of toxic and hazardous substance into rivers and their long-term legacies are widely recognized. For example, chloride pollution in the Rhine is expected to persist for several centuries, forcing France to face a salinity problem on its Alsace aquifer (see Vörösmarty et al. 2015). The long-term legacies of historical events are, however, only slowly getting the scrutiny of river ecologists and managers (but see, e.g., EEA 2001, 2013).

Pollution with heavy metals from mining and ore processing has been relevant throughout history. Several studies exist, for instance, for the mining of mercury in support of large-scale gold and silver exploitation and production since the sixteenth century in Europe and America. Recently, Torkar and Zwitter (2015) investigated the long-term effects of the Slovenian mercury mine in Idrija and the resulting pollution of Idrijca River on fish. Polluted sediments were swept downstream and finally accumulated in the sediments of the northern part of the Gulf of Trieste (Gosar 2008; Foucher et al. 2009). According to Nriagu (1994), the annual loss of mercury in the silver mines of Spanish America averaged 612 tons per year between 1580 and 1900. Total losses of mercury to the environment in the Americas within 
this period amounted to 257,400 tons. Approximately $60-65 \%$ was released to the atmosphere, but large quantities of mercury were deposited on terrestrial and riverine ecosystems from where they may be reemitted. Concerning most of the mercury now sequestered in the sediments of aquatic systems-mainly in marine sediments, Camargo (2002) concluded, however, that the high mercury concentrations currently reported in the global environment are a consequence of the huge pollution caused by human activities during the twentieth century.

The long-term legacies of past sediment pollution have been recognized for the Danube catchment where the risk of accidental release and remobilization of hazardous substances stored in the soils from past industrial activities or waste disposal was identified. An inventory of accident risk spots was elaborated. By 2009, a total of approximately 650 such spots were reported in the flood-prone zones of the entire river basin and 620 were evaluated. Here, a hazardous equivalent of 6.6 million tons has been identified as a potential danger (ICPDR 2009).

\subsubsection{Land-Use Change, Hydrology, and Erosion}

Land-use change was an indirect but nevertheless severe human impact to preindustrial streams. The large-scale medieval shift from forests to arable land in Europe triggered more rapid surface runoff and erosion, reduced evapotranspiration, and increased the discharges of rivers. Bork et al. (1998) investigated land-use change and its environmental effects for Germany north of the Alps based on palynological and pedological data and demonstrated its strong imprint. Around $650 \mathrm{CE}, 93 \%$ of the total area was covered by woods $\left(697,500 \mathrm{~km}^{2}\right.$ out of a total of $750,00 \mathrm{~km}^{2}$ ). By 1310 , the proportion of woods had diminished to $15 \%$ only (i.e., $112,500 \mathrm{~km}^{2}$ ) mostly in favor of arable land and grassland. At present, forests cover about one third, arable land $38 \%$, and grassland about $24 \%$. Other land-use types were always of minor importance. Assuming that mean annual precipitation was similar for all periods and amounted to $700 \mathrm{~mm}$ per year, total annual surface runoff more or less doubled from $115 \mathrm{~mm}$ in 650 to $245 \mathrm{~mm}$ in 1310 . At present, total annual surface runoff is assumed to be around $220 \mathrm{~mm}$. Although Bork et al. (1998) did not specifically investigate the effects of altered surface runoff on river discharge, they conclude that changed evapotranspiration and interception had an effect. The Wassermühlenthese mentioned above clearly points to this link between surface runoff and springs' and rivers' discharges.

Land-use and land-cover change clearly correlated with erosion rates. From the seventh to the end of the tenth century (max. proportion of arable land 20\%), for instance, in all of Germany north of the Alps, an annual rate of up to about 9 million tons eroded into river channels. During the first half of the fourteenth century, when forests covered only $15 \%$, the share of arable land had risen to more than $50 \%$ (about $55 \%$ in 1313-1318), and extreme precipitation events were frequent, annual erosion reached 1900 Mio tons between 1313 and 1318. They peaked at 13,000 Mio tons in 1342, when a 1000-year recurrence flood hit large areas of central Europe. In the 
second half of the fourteenth century, erosion rates declined together with less wet climate and an increasing proportion of forests recolonizing arable land. The latter was abandoned due to declining human population after the first wave of plague in $1347-1353$. Only in the 1780s and in the following decades a new increase to 200 Mio tons per year was noticed - a resurgence due to expansion of arable land and a new period of intensified and more frequent rainstorms (see Bork et al. 1998; but also Lang et al. 2000; Dreibrodt et al. 2010; Dotterweich and Dreibrodt 2011; Brázdil et al. 2005). In total, it is assumed that half of the total erosion that can be observed in Germany between the seventh and the twentieth century took place from 1310 to 1342 (Lang et al. 2000).

In North America and Australia, European settlers introduced new land-use practices that increased erosion. However, changes in sedimentation rates and river morphology date back to native population influences (Overeem et al. 2013). In New Zealand, increase of sediment loads started in the North Island rivers already with the Maoris, and similar trends are associated with cultivation practices of the Native American population. Along the Waipaoa River in New Zealand, sediment yields increased by $140 \%$ after Polynesians had arrived between 1250 and $1300 \mathrm{CE}$. They settled mainly along coastal areas and kept erosion and sediment yield increase comparatively low. This differed from European settlers arriving in the eighteenth century. Their land-use change affected lower and upper catchments and sediment yields increased by $660 \%$ (Overeem et al. 2013).

A direct link between land-use change, soil erosion rates, and alluvial sediments is hard to prove. Dating is usually difficult due to the reworking of sediment layers in rivers (Dotterweich 2008; Dreibrodt et al. 2010). Few case studies have investigated, however, the link between increased alluvial sedimentation, land-use change, and extreme precipitation events (Dotterweich 2008; Lang 2003; Lang et al. 2000). Giosan et al. (2012) demonstrated that long-term land-use change in the Danube catchment contributed in the Holocene and, in particular, over the last 1000 years to the evolution of the Danube delta. Human impacts vs. long-term historical climate and subsequent hydrology changes were examined as possible drivers of increased sediment storage rates, and Giosan et al. (2012) found that land-use change was the main factor. Sedimentation rates increased, in particular, after land clearance, affecting also the lower Danube at larger scales during the last two centuries (see also McCarney-Castle et al. 2012). Maselli and Trincardi (2013) found similar trends when comparing the Ebro, Rhona, Po, and Danube. They found two main phases of delta growth. One synchronous increase happened during Roman times under relatively warm climatic conditions, a second during the Little Ice Age. The latter shows, however, slight temporal differences since delta growth coincides temporally mainly for the Ebro, Rhone, and Po (between the sixteenth and twentieth centuries), whereas in the Danube delta growth was found mostly in the nineteenth century and thereafter. Alterations of morphological river types and subsequent habitat change affected riverine fish assemblages as it was shown by Pont et al. (2009) for the Drome River, a tributary of the French Rhone. 


\subsubsection{Fisheries: Intended and Unintended Dispersal of Nonnative Species}

Most human uses and their ecological impacts changed aquatic biota indirectly via habitat modification. Fishing was one exception as it altered stocks directly. Also, until the twentieth century, the appearance of nonnative species was caused mainly by deliberate introductions by fisheries management (however, cf. nonnative fish distribution as a consequence of artificial shipping canals above). Only during the twentieth century, the unintended dispersal of nonnative and invasive fish species and other aquatic animals and plants via transport means increased drastically.

It is evident that fishing put direct stress on the targeted fish populations and changed species assemblages already centuries ago. A remarkable recorded example of medieval overexploitation is the Alpine Zellersee in Austria. After the 1360s, fishermen delivered each year 27,000 whitefish (Coregonus sp.) and 18 lake trout (Salmo trutta) to the archbishop of Salzburg, taking themselves even more for their own use. Only some decades later the whitefish population collapsed. Pike (Esox lucius) was stocked to replace it. When predating pikes had soon diminished trout stocks, only then did the fishing communities decide to reduce fishing pressure (Freudlsperger 1936).

Particularly subjected to overexploitation were diadromous fish because of their predictable spawning runs during which large amounts could be caught. For example, archaeological sturgeon remains from the southern Baltics demonstrate a decrease of average size of specimen and a decline of the percentage in total consumption from $70 \%$ in the seventh, eighth, and ninth centuries to only $10 \%$ in the twelfth and thirteenth centuries CE. Benecke (1986) clearly attributed this change to overfishing. Weirs built since the High Middle Ages in Europe supported overexploitation (Hoffmann 1996).

Such evidence for declining fish populations are rare for the medieval and even for modern periods. Due to lack of written historical sources that enable tracing depletion of certain fish species and their stocks, it is hardly possible to directly quantify losses before the twentieth century. Nevertheless, some indications help explain the preindustrial decline of fish. As mentioned already above, the latter can be concluded indirectly from fishing laws that were issued in Europe since the thirteenth century (Hoffmann 1996). The laws aimed first at protecting juveniles by regulating minimum lengths or weights of individuals, by forbidding harmful fishing gear, or by defining closed seasons. In contrast, habitat protection is rather a practice of the nineteenth century and afterward.

While overexploitation of fish in the medieval and early modern period took place especially in European countries, North America and Australia followed this pattern after the colonization of European settlers. Travelers' accounts describe the wealth of freshwater fish, e.g., in the Ohio River which was said to have been inhabited by enormous numbers of pike, walleye, catfish, buffalo fish, suckers, drum, and sturgeon as well as small fish such as sand darters, chub, riffle darters, and minnows (Trautman 1981 cited from Humphries and Winemiller 2009). Massive exploitation 
with a variety of fishing nets, dams to support fishing, as well as milldams hampering fish migration soon raised concern of overexploitation. As in Europe, also in North America fishing regulations followed. The number of fishing days per week was reduced, fishing gear regulated, and closed seasons defined, for example, in Massachusetts in 1710, in Connecticut in 1715, or in Rhode Island in 1735 (Humphries and Winemiller 2009). Sturgeon fishes (Acipenser oxyrinchus, A. brevirostris), salmon, or shad (Clupea sapidissima) were among the fish stocks which have been overfished so heavily that fishing them in the seventeenth and eighteenth centuries was stopped several times after few years of fishing because stocks were too low (Lichter et al. 2006). In North America, the settlers also established a lively beaver trading industry. Hunting beavers began in the early seventeenth century. Between 1630 and 1640, 80,000 individuals were caught annually. By 1900, this species was more or less extinct in North America (Naiman et al. 1988; cited from Humphries and Winemiller 2009). In the late nineteenth and twentieth century, river channelization, flood protection dikes, hydropower dams, and pollution added to the adverse effects of fish overexploitation in most of Western rivers. It is assumed that in Europe 13 fish species have gone extinct since 1700 (Kottelat and Freyhof 2007). A large number of fish species is threatened, especially less tolerant species requiring specific habitats.

Purposeful and unintended species introduction contributed to large-scale changes in fish assemblages. Fish pond networks and fish breeding programs were established to ensure a sufficient and steady supply of a resource that is naturally only seasonally available. Historical records confirm this started in Western Europe in the eleventh century and spread eastward in the twelfth and thirteenth centuries (Hoffmann 1996). Originally, different kinds of cyprinids were raised in the ponds because they could tolerate consistently warm temperatures. Soon, carp (Cyprinus carpio), a fish species native to the middle and lower Danube watershed, became the main species as they tolerate longer land transport, have a high fecundity, and grow relatively fast. The earliest traces mark the spread of carps to the upper Danube, the Elbe, or the Rhine in the eleventh and twelfth centuries and to the Maas, Seine, or upper Rhone in the late twelfth and thirteenth centuries. The dispersal into central Bohemia, Southern Poland, the Loire, and southern England happened in the Late Middle Ages. From ponds, carp reached natural waters and had colonized suitable habitats in most of Central, Western, and Northern Europe by 1600 (Hoffmann 1996).

It can be assumed that with the transfer of carp also other species were unintentionally spread and colonized new river systems. Evidence suggests that Bitterling (Rhodeus amarus) was introduced to many rivers of Central and Western Europe in a first wave already in the High and Late Middle Ages (1150-1560) together with carp (Damme et al. 2007). It is not possible to trace the origin of tench (Tinca tinca) in sixteenth century Spain where it occurred together with carp (Clavero and Villero 2014).

In contrast to many other domesticated animal and plant species, which were transferred purposefully between the continents after the discovery of the Americas, the so-called Columbian Exchange hardly affected riverine environments in the 
Early Modern Period, i.e., the sixteenth and seventeenth century (Crosby 1972). A few-though delayed-exceptions are ornamental fish or species that were introduced to help fighting mosquitos. The goldfish (Carassius auratus) was brought to Portugal in 1611. In England and France, it was imported in eighteenth century (Copp et al. 2005). The mosquitofish (Gambusia holbrooki) was introduced in Europe in the 1920s (Vidal et al. 2010).

Introduction of nonnative fish species and the large-scale spread of invasive fish are clearly attributed to industrialized rivers. With railways, fresh fish could be imported in unprecedented quantities to continental areas. In Vienna, for example, the import of fish from the North Sea started in 1899 when a German steam fish trading company opened its first stand on the Viennese fish market. Only due to these imports the yearly amounts sold on the market could increase from 600 to 2250 tons between 1880 and 1914, securing fish as nutrition for the heavily growing population (Jungwirth et al. 2014). Concurrently, local fish stocks in the Danube exhibited a clear downward trend as they started to be seriously affected by systematic channelization measures for navigation and partly for flood protection.

Although fisheries can be seen as victims of the industrialization of rivers, fishermen eagerly adapted new technologies, thereby contributing seriously on their own to the change of riverine fish assemblages. They began artificial fish breeding and stocking and often the efforts of European fishermen targeted North American fish species since they were considered faster growing and sometimes also better adapted to channelized habitats. Intentional fish translocations happened on a continental as well as an intercontinental scale. In Europe, for instance, catfish (Silurus glanis) or pike-perch (Sander lucioperca) were introduced in Western Rivers in the nineteenth century (see, e.g., Copp et al. 2005). Modern steam ships enabled relatively easy exchange between the continents, first and foremost between Europe and North America. Rainbow trout (Oncorhynchus mykiss)_native to North American and North Asian streams of the Pacific-was one of the main species. In the USA, its artificial breeding for stocking of native and nonnative environments started in the 1870s (Halverson 2010). Import to Europe followed soon after in the 1880s. Brook trout (Salvelinus fontinalis), brown bullhead (Ameiurus nebulosus), pumpkinseed (Lepomis gibbosus), or smallmouth bass (Micropterus dolomieu) were other target species. Some of the nonnative species introduced in Europe established self-sustaining populations, e.g., rainbow trout or brook trout (Copp et al. 2005).

\subsection{Conclusions}

The historical evolution of river uses and resulting ecological impacts exhibit clear temporal patterns. It is evident that human alterations have been numerous for millennia. Preindustrial effects were mostly local and regional, and human practices, such as passive flood protection, were designed to adapt to, not control, the dynamics of rivers. This relates, for instance, to ancient Egypt and likewise to European preindustrial practices of flood protection that depended on measures to mitigate 
flood damages (see Chap. 28). In intensely populated regions, such adaptive practices at local scales could aggregate up to larger-scale effects. Characteristic for preindustrial rivers is that local aquatic environmental resources were essential for societies. Since substitution by trade was not yet possible, harmonizing a variety of uses was indispensable. This helped keep ecological impacts at low levels. Preindustrial societies, nevertheless, initiated long-term changes of river ecosystems that might influence them even in the present era. Land-use change and erosion as well as weirs as sediment traps are prime cases. Although reliable and detailed records are scarce, it seems that subsequent examples include stocking of nonnative fish species and unintended expansion of fish and other species, for instance, via shipping canals built in and after the seventeenth century contributed to early modifications of aquatic biota and biotic communities. One should note that, in contrast to (well-studied) marine systems (see, e. g., Jackson et al. 2001), in rivers overexploitation, primarily of aquatic animals, was soon followed by effects of other human uses on habitat conditions.

Industrialization had large-scale effects on river uses and their impacts on morphology, hydrology, and aquatic biota. The use of fossil energy enabled intensification of uses with unprecedented ecological consequences. Well into the twentieth century, deteriorating water quality and hydromorphological degradation were perceived as a necessary evil to foster economic development. Riverine impairment peaked in response to a combination of intensifying factors: increasing resource exploitation and use, a rising density of machinery in industry and private households, intensified agriculture driven by an ever-increasing number of machines, as well as fertilizers and pesticides.

As a response in the late 1980s and 1990s, river restoration projects were planned and implemented. Especially in densely populated areas and centers of economic production, rivers and their biotic communities often have been degraded so drastically that restoration toward a natural status appears impossible within any foreseeable political time frame (see, e.g., Hughes et al. 2005; Dufour and Piégay 2009). In addition, some external factors, namely, climate and thus hydrology and temperature, changed naturally as well as due to human impacts for more than a century. This further prevents restoration of presumed pristine conditions. While this might confine the role of history in defining reference conditions, historical investigation of rivers can nevertheless add valuable insights into their trajectories and help explaining the origins of present conditions.

\section{References}

Allan JD, Abell R, Hogan Z, Revenga C, Taylor BW, Welcomme RL, Winemiller K (2005) Overfishing of inland waters. Bioscience 55:1041-1051

Barles S (2007) Feeding the city: food consumption and flow of nitrogen, Paris, 1801-1914. Sci Total Environ 375:48-58 
Barles S (2012) The seine and Parisian metabolism: growth of capital dependencies in the 19th and 20th centuries. In: Castonguay S, Evenden MD (eds) Urban waters: rivers, cities and the production of space in Europe and North America. Pittsburgh University Press, Pittsburgh, pp 94-112

Benecke N (1986) Some remarks on sturgeon fishing in the southern Baltic region in medieval times. In: Brinkhuizen DC, Clason AT (eds) Fish and archaeology. British Archaeological Reports, Oxford, pp 9-17

Billen G, Garnier J, Deligne C, Billen C (1999) Estimates of early-industrial inputs of nutrients to river systems: implication for coastal eutrophication. Sci Total Environ 243:43-52

Billen G, Garnier J, Barles S (2012) History of the urban environmental imprint: introduction to a multidisciplinary approach to the long-term relationships between western cities and their hinterland. Reg Environ Chang 12:249-253

Bork H-R, Bork H, Dalchow C, Faust B, Piorr H-P, Schatz T (1998) Landschaftsentwicklung in Mitteleuropa (Wirkungen des Menschen auf Landschaften). Klett-Perthes, Gotha

Braudel F (1986) Aufbruch zur Weltwirtschaft. Sozialgeschichte des 15.-18. Jahrhunderts, vol 3. Kindler, München

Brázdil R, Pfister C, Wanner H, Storch HV, Luterbacher J (2005) Historical climatology in Europe - the state of the art. Clim Chang 70:363-430

Brolsma JU (2011) A brief history of inland navigation and waterways - the development of the waterway infrastructure in the Netherlands. RWS Centre for Transport and Navigation, Delft

Bundi M (1988) Von Fischpässen und -treppen einst und heute. Bündner Kalender 1988:70-73

Camargo JA (2002) Contribution of Spanish-American silver mines (1570-1820) to the present high mercury concentrations in the global environment: a review. Chemosphere 48:51-57

Clavero M, Villero D (2014) Historical ecology and invasion biology: long-term distribution changes of introduced freshwater species. Bioscience 64:145-153

Copp GH, Bianco PG, Bogutskaya NG, Erős T, Falka I, Ferreira MT, Fox MG, Freyhof J, Gozlan RE, Grabowska J, Kovac V, Moreno-Amich R, Naseka AM, Penaz M, Povz M, Przybylski M, Robillard M, Russell IC, Stakenas S, Sumer S, Vila-Gispert A, Wiesner C (2005) To be, or not to be, a non-native freshwater fish? J Appl Ichthyol 21:242-262

Crosby AW (1972) The Columbian exchange: biological and cultural consequences of 1492. Greenwood Press, Westport Conn

Damme DV, Bogutskaya N, Hoffmann RC, Smith C (2007) The introduction of the European bitterling (Rhodeus Amarus) to west and Central Europe. Fish Fish 8:79-106

Dotterweich M (2008) The history of soil erosion and fluvial deposits in small catchments of Central Europe: deciphering the long-term interaction between humans and the environment - a review. Geomorphology 101:192-208

Dotterweich M, Dreibrodt S (2011) Past land use and soil erosion processes in Central Europe. PAGES News 19:49-51

Downs P, Gregory K (2004) River Channel management: towards sustainable catchment hydrosystems. Taylor \& Francis, New York

Dreibrodt S, Lubos C, Terhorst B, Damm B, Bork HR (2010) Historical soil erosion by water in Germany: scales and archives, chronology, research perspectives. Quat Int 222:80-95

Dufour S, Piégay H (2009) From the myth of a lost paradise to targeted river restoration: forget natural references and focus on human benefits. River Res Appl 25:568-581

EEA - European Environment Agency (2001) Late lessons from early warnings: the precautionary principle 1896-2000. EEA, Luxembourg

EEA - European Environment Agency (2013) Late lessons from early warnings: science, precaution, innovation. EEA, Luxemburg

Foucher D, Ogrinc N, Hintelmann H (2009) Tracing mercury contamination from the Idrija mining region (Slovenia) to the Gulf of Trieste using $\mathrm{Hg}$ isotope ratio measurements. Environ Sci Technol 43:33-39

Freudlsperger H (1936) Kurze Fischereigeschichte des Erzstiftes Salzburg. Mitteilungen der Gesellschaft für Salzburger Landeskunde 76:81-128 
Gierlinger S, Haidvogl G, Gingrich S, Krausmann F (2013) Feeding and cleaning the city: the role of the urban waterscape in provision and disposal in Vienna during the industrial transformation. Water Hist 5:219-239

Giosan L, Coolen MJL, Kaplan JO, Constantinescu S, Filip F, Filipova-Marinova M, Kettner AJ, Thom N (2012) Early anthropogenic transformation of the danube-black sea system. Sci Rep $2: 1-6$

Gleick PH (ed) (1993) Water in crisis. A guide to the world's freshwater resources. Oxford University Press, New York

Gosar M (2008) Mercury in river sediments, floodplains and plants growing thereon in drainage area of Idrija mine, Slovenia. Pol J Environ Stud 17(2):227-236

Green PA, Vörösmarty CJ, Meybeck M, Galloway JN, Peterson BJ, Boyer EW (2004) Pre-industrial and contemporary fluxes of nitrogen through rivers: a global assessment based on typology. Biogeochemistry 68:7-105

Gregory KJ (2006) The human role in changing river channels. Geomorphology 79:172-191

Haidvogl G (2008) Von der Flusslandschaft zum Fließgewässer: die Entwicklung ausgewählter österreichischer Flüsse im 19. und 20. Jahrhundert mit besonderer Berücksichtigung der Kolonisierung des Überflutungsraums. Dissertation Universität Wien

Haidvogl G, Preis S (2003) Anthropogene Nutzungen und Eingriffe in und an der Möll um 1830 am Beispiel von zwei ausgewählten Abschnitten. Un-published dataset. Institut für Hydrobiologie und Gewässermanagement, Universität für Bodenkultur, Vienna

Haidvogl G, Guthyne-Horvath M, Gierlinger S, Hohensinner S, Sonnlechner C (2013) Urban land for a growing city at the banks of a moving river: Vienna's spread into the Danube island Unterer Werd from the late 17th to the beginning of the 20th century. Water Hist 5:195-217

Haidvogl G, Lajus D, Pont D, Schmid M, Jungwirth M, Lajus J (2014) Typology of historical sources and the reconstruction of long-term historical changes of riverine fish: a case study of the Austrian Danube and Northern Russian rivers. Ecol Freshw Fish 23:498-515

Haidvogl G, Hoffmann R, Pont D, Jungwirth M, Winiwarter V (2015) Historical ecology of riverine fish in Europe. Aquat Sci 77:315-324

Halverson A (2010) An entirely synthetic fish: how rainbow trout beguiled America and overran the world. Yale University Press, London

Hassan F (2011) Water history for our times. IHP essays on water history 2. Unesco, Paris

Higgs E, Falk DA, Guerrini A, Hall M, Harris J, Hobbs RJ, Jackson ST, Rhemtulla JM, Throop W (2014) The changing role of history in restoration ecology. Front Ecol Environ 12:499-506

Hoffmann RC (1996) Economic development and aquatic ecosystems in medieval Europe. Am Hist Rev 101:631-669

Hohensinner S, Habersack H, Jungwirth M, Zauner G (2004) Reconstruction of the characteristics of a natural alluvial river-floodplain system and hydromorphological changes following human modifications: the Danube river (1812-1991). River Res Appl 20:25-41

Hohensinner S, Lager B, Sonnlechner C, Haidvogl G, Gierlinger S, Schmid M, Krausmann F, Winiwarter V (2013) Changes in water and land: the reconstructed Viennese riverscape from 1500 to the present. Water Hist 5:145-172

Hughes FMR, Colston A, Mountford JO (2005) Restoring riparian ecosystems: the challenge of accommodating variability and designing restoration trajectories. Ecol Soc 10. http://www. ecologyandsociety.org/vol10/iss1/art12/

Humphries P, Winemiller K (2009) Historical impacts on river fauna, shifting baselines, and challenges for restoration. Bioscience 59:673-684

ICOLD - International Commission on Large Dams (2007) Dams and the world's water. An educational book that explains how dams help to manage the world's water. ICOLD, Paris

ICOLD - International Commission on Large Dams (2016) http://www.icold-cigb.net/GB/World_ register/general_synthesis.asp?IDA=212. Accessed 18 Jul 2016

ICPDR - International Commission for the Protection of the Danube River (2009) Danube river basin management plan. ICPDR, Vienna 
Jackson JBC, Kirby MX, Berger WH, Bjorndal KA, Botsford LW, Bourque BJ, Bradbury RH, Cooke R, Erlandson J, Estes JA, Hughes TP, Kidwell S, Lange CB, Lenihan HS, Pandolfi JM, Peterson CH, Steneck RS, Tegner MJ, Warner RR (2001) Historical overfishing and the recent collapse of coastal ecostystems. Science 293:629-637

Jakobsson E (2002) Industrialization of rivers: a water system approach to hydropower development. Knowl Technol Policy 14:41-56

Jungwirth M, Haidvogl G, Hohensinner S, Waidbacher H, Zauner G (2014) Österreichs Donau. Landschaft - Fisch - Geschichte. Institut für Hydrobiologie und Gewässermanagement. Universität für Bodenkultur, Wien

Kottelat M, Freyhof J (2007) Handbook of European freshwater fishes. Eigenverlag, Cornol

Kraikovsky A, Lajus J (2010) The neva as a metropolitan river of Russia: environment, economy and culture. In: Tvedt T, Coopey R (eds) A history of water, series II, 2, rivers and society: from early civilizations to modern times. I.B. Tauris, London, pp 339-364

Lang A (2003) Phases of soil erosion-derived colluviation in the loess hills of South Germany. Catena 51:209-221

Lang A, Preston N, Dickau R, Bork H-R, Mäckel R (2000) LUCIFS - examples from the Rhine catchment. PAGES News 8:11-13

Lehner B, Reidy Liermann C, Revenga C, Vörösmarty C, Fekete B, Crouzet P, Döll P, Endejan M, Frenken K, Magome J, Nilsson C, Robertson JC, Rödel R, Sindorf N, Wisser D (2011a) Global reservoir and dam database, version 1 (GRanDv1): dams, revision 01, NASA Socioeconomic Data and Applications Center (SEDAC), Palisades, New York. https://doi.org/10.7927/ H4N877QK. Accessed 4 Oct 2017

Lehner B, Liermann CR, Revenga C, Vörösmarty C, Fekete B, Crouzet P, Döll P, Endejan M, Frenken K, Magome J, Nilsson C, Robertson JC, Rödel R, Sindorf N, Wisser D (2011b) Highresolution mapping of the world's reservoirs and dams for sustainable river-flow management. Front Ecol Environ 9:494-502

Leitholdt E, Zielhofer C, Berg-Hobohm S, Schnabl K, Kopecky-Hermanns B, Bussmann J, Härtling JW, Reicherter K, Unger K (2012) Fossa Carolina: the first attempt to bridge the Central European watershed - a review, new findings, and geoarchaeological challenges. Geoarchaeology 27:88-104

Lichter J, Caron H, Pasakarnis TS, Rodgers SL, Squiers TS Jr, Todd CS (2006) The ecological collapse and partial recovery of a freshwater tidal eco system. Northeast Nat 13:153-178

Liu C, Kroeze C, Hoekstra AY, Gerbens-Leenes W (2012) Past and future trends in grey water footprints of anthropogenic nitrogen and phosphorus inputs to major world rivers. Ecol Indic $18: 42-49$

Maselli V, Trincardi F (2013) Man made deltas. Sci Rep 3:1926

McCarney-Castle K, Voulgaris G, Kettner AJ, Giosan L (2012) Simulating fluvial fluxes in the Danube watershed: the 'little ice age' versus modern day. The Holocene 22:91-105

Micklin P (2007) The Aral Sea disaster. Annual review earth. Planet Sci 35:47-72

Mieck I (1981) Die Anfänge der Umweltschutzgesetzgebung in Frankreich. Francia 9:332

Möser K (2008) Prinzipielles zur Transportgeschichte. In: Sieferle RP (ed) Transportgeschichte. Der Europäische Sonderweg, vol 1. LIT, Berlin, pp 39-78

Naiman RJ, Johnston CA, Kelley JC (1988) Alteration of North American streams by beaver. Bioscience 38:753-762

Nelva A (1997) La pénétration du Hotu, Chondrostoma nasus nasus (Poisson Cyprinidé), dans le réseau hydrographique français et ses conséquences. Bull Fr Pêche Piscic 344-345:253-269

Nriagu JO (1994) Mercury pollution from the past mining of gold and silver in the Americas. Sci Total Environ 149:167-181

Overeem I, Kettner AJ, Syvitski JPM (2013) 9.40 impacts of humans on river fluxes and morphology A2. In: Shroder John F (ed) Treatise on geomorphology. Academic Press, San Diego, pp $828-842$

Petts GE, Möller H, Roux AL (eds) (1989) Historical change of large alluvial rivers: Western Europe. Wiley, Chichester 
Poff NL, Hart DD (2002) How dams vary and why it matters for the emerging science of dam removal. Bioscience 52:659-668

Pont D, Piégay H, Farinetti A, Allain S, Landon N, Liébault F, Dumont B, Richard-Mazet A (2009) Conceptual framework and interdisciplinary approach for the sustainable management of gravel-bed rivers: the case of the Drome River basin (S.E. France). Aquat Sci 71:356-370

Pounds N (1979) An historical geography of Europe. 1500-1840. Cambridge University Press, Cambridge

Raab A (1978) Die traditionelle Fischerei in Niederösterreich, mit besonderer Berücksichtigung der Ybbs, Erlauf, Pielach und Traisen. Dissertation, Universität Wien, Wien

Rosenberg DM, McCully P, Pringle CM (2000) Global-scale environmental effects of hydrological alterations: introduction. Bioscience 50:746-751

Sieferle RP (2006) Das Ende der Fläche - zum gesellschaftlichen Stoffwechsel der Industrialisierung. Böhlau, Köln

Sieferle RP (ed) (2008) Transportgeschichte. Der Europäische Sonderweg, vol 1. LIT, Berlin

Stergiouli ML, Hadjibiros K (2012) The growing water imprint of Athens (Greece) throughout history. Reg Environ Chang 12:337-345

Strayer DL, Dudgeon D (2010) Freshwater biodiversity conservation: recent progress and future challenges. J N Am Benthol Soc 29:344-358

Tello E, Ostos J (2012) Water consumption in Barcelona and its regional environmental imprint: a long-term history (1717-2008). Reg Environ Chang 12:347-361

Torkar G, Zwitter Ž (2015) Historical impacts of mercury mining and stocking of non-native fish on ichthyofauna in the Idrijca River basin, Slovenia. Aquat Sci 77:381-393

Trautman MB (1981) The fishes of Ohio: with illustrated keys. Ohio State University Press, in collaboration with the Ohio Division of Wildlife and the Ohio State University Development Fund

Vella C, Leveau P, Provansal M, Gassend JM, Maillet B, Sciallano M (1999) Le canal de Marius et les dynamiques littorales du golfe de fos. Gallia 56:131-139

Vidal O, García-Berthou E, Tedesco PA, García-Marín J-L (2010) Origin and genetic diversity of mosquitofish (Gambusia holbrooki) introduced to Europe. Biol Invasions 12:841-851

Vitousek PM (1994) Beyond global warming: ecology and global change. Ecology 75:1861-1876

Vogemont L (1712) Teutschlands vermehrter Wohlstand, oder Vorstellung einer grundmässigen Einrichtung der Handlung, wie nemblich solche in Teutschland, durch Schiffreichmachung derer Flüsse, zu wegen gebracht werden könne. Johann Georg Schlegl, Wien

Vörösmarty CJ, Meybeck M, Pastore CL (2015) Impair-then-repair: a brief history \& global-scale hypothesis regarding human-water interactions in the anthropocene. Daedalus 144:94-109

Walter RC, Merritts DJ (2008) Natural streams and the legacy of water-powered mills. Science 319:299-304

Zarfl C, Lumsdon A, Berlekamp J, Tydecks L, Tockner K (2015) A global boom in hydropower dam construction. Aquat Sci 77:161-170

Zösmair J (1886) Die Geschichte der Fischerei in der Ill. Feldkircher Zeitung 26(97):1-3

Open Access This chapter is licensed under the terms of the Creative Commons Attribution 4.0 International License (http://creativecommons.org/licenses/by/4.0/), which permits use, sharing, adaptation, distribution and reproduction in any medium or format, as long as you give appropriate credit to the original author(s) and the source, provide a link to the Creative Commons license and indicate if changes were made.

The images or other third party material in this chapter are included in the chapter's Creative Commons license, unless indicated otherwise in a credit line to the material. If material is not included in the chapter's Creative Commons license and your intended use is not permitted by statutory regulation or exceeds the permitted use, you will need to obtain permission directly from the copyright holder.

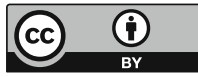

